\title{
IAMJ
}

INTERNATIONAL

AYURVEDIC

MEDICAL JOURNAL

\section{UNDERSTANDING THE RELATION BETWEEN MANSIK BHAVAS AND VYADHI UTPATTI W.S.R. IMMUNITY}

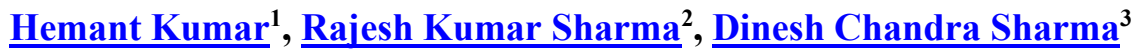 \\ ${ }^{1}$ P.G. Scholar, ${ }^{2}$ Associate Professor and H.O.D., ${ }^{3}$ Assistant Professor, \\ P.G. Department of Kriya Sharir, DSRRAU, Jodhpur, Rajasthan, India
}

Corresponding Author: hemantgarghunny@gmail.com

\section{https://doi.org/10.46607/iamj2608092020}

(Published online: September 2020)

Open Access

(C) International Ayurvedic Medical Journal, India 2020

Article Received:09/08/2020 - Peer Reviewed:12/09/2020 - Accepted for Publication:12/09/2020

Check for updates

\begin{abstract}
Whenever there for time of crisis in pandemic (like corona in present time), indication to 'do not panic' are always given to society. Why?. Is there any relation of doing panic and getting the disease? Is there any possibility of Mansik Bhavas like anger (Krodha), grief (Shoka), anxiety (Chinta), fear (Bhaya) can be the cause or precipitating factor of infection to any person?

Both Ayurveda and modern point of view agrees to the statement that different Mansik Bhavas like Chinta, Shoka, Kama, Krodh, etc. can lead to or can act as Hetu for any disease and hence there is existence of relation between these Mansik Bhavas and Sharirik Vyadhi Utpatti.

Immunity is a condition of being able to resist a particular disease especially through preventing development of a pathogenic microorganism or by counteracting the effects of its products ${ }^{1}$. It means that whenever any disease occurs there must be some loss of immunity in the related system and the factors responsible for the disease are the cause for lowering the immune response which ultimately indicates the effect of different psychological behaviors on immunity of the body.

Ayurvedic texts are full of examples where Mansik Bhavas are mentioned as Hetu in many diseases. Acharya Charak mentioned in Vimanasthan chapter 6 that there is a relation between Sharirik and Mansik Doshas.
\end{abstract}


In this review article we will understand the Role of Mansik Bhavas in Sharirik Vyadhi Utpatti with different reference given in Ayurvedic texts and what can be the probable cause of that in terms of immunity according to modern researches.

Keywords: Mansik Bhavas, immunity, Ayurveda, Bhaya, Shoka, Krodha, Chinta.

\section{INTRODUCTION}

Ayurveda is the science of life. It deals with Physical, Psychological as well as Spiritual wellbeing of an individual. It covers every possible aspect which can affect the $A y u$ (age) in any possible way. And hence it focuses on both- "Swasthsyasawaasthrakshanam and Aatursayavikaarprashaman". Grossly there are two types of disease Sharirika (Somatic) and Manasika (Psychic) according to the location of disease. Acharya Charak mentioned about the involvement of mansik and sharirik dosha in each other with time. Chakrapani further interprets and elaborates their context and strongly postulates the psychosomatic concept of Ayurveda as ShariranamSharirena, ManasanamManasena, ShariranamManasena, $\quad \mathrm{Ma}$ nasanamSharirena. Immunity is a condition of being able to resist a particular disease especially through preventing development of a pathogenic microorganism or by counteracting the effects of its products. It means that whenever any disease occurs there must be some loss of immunity in the related system and the factors responsible for the disease must be the cause for lowering the immune response. This is why Various Manasika bhavas (Emotions) are described in Ayurveda as the root cause of many diseases. Lust (Kama), anger (Krodha), greed (Lobha), delusion (Moha), jealousy (Irsya), grief (Shoka), anxiety (Chinta), fear (Bhaya) etc. are various Manasika Bhavas and disturbance in these Manasika Bhava disturbs the homeostasis of both body and mind by vitiating $\mathrm{Ma}$ nasdosha, Sharirikadosha \& Agni.

\section{Manasa Bhavas and Their Effects on Body²-}

Bhaya (Fear): It is a condition precipitated by dreadful act. It develops due to facing unwanted situation. Rajodosha is mainly involved. Bhaya is a human emotion which makes person incapable of doing anything as a result of which mana of a person becomes restless. Increase in Bhaya further leads to increase in
Vatadosha which can lead to Anidra. The victim of Bhaya can suffer from Diarrhoea. Acharya Charaka has mentioned Bhayaja Atisara among its 6 types. Its intensity is examined by Vishada. In fear the punishment center of the limbic system is activated. It turns on the autonomic response of fight-or-flight response. Stimulation of a thin zone of periventricular nuclei of thalamus, located immediately adjacent to the third ventricle usually leads to fear. Tremors in the body parts, dryness of mouth sweating, giddiness, Moha are the symptoms of Bhaya. A sudden exposure to Bhaya may lead to many physical and mental diseases.

Chinta (Worry): There is increase in Sukshmaguna of vata due to Atiyoga of Chinta which causes increase in mental vibrations. Hence mind becomes restless leading to lack of Nidra. Sometimes individual suffer from an emotional disorder, which is psychologically just as disabling as the more extreme forms of fear but in which the individual really does not know, of what he is afraid, this is known as Chinta. Neurotic anxiety is perhaps the most important of all the symptoms in the sphere of emotions of psychopathology. The physiological concomitants which characterizes anxiety are increase blood pressure, tachycardia, increased respiration, tremors and sweating.

Krodha (Anger): One of the evils found within human mind. Krodha originates from the Rajoguna and the main feature is to do harm to others. It vitiates Vata and Pitta and produces symptoms accordingly. This causes Daha in whole body and stimulation of Mana, further causing Anidra. The degree of anger can be measured on the basis of intensity of Droha found in a person. Some people, when they are angry, have stomach trouble at the same time or grow red in the face. Their circulation is altered to such a degree that a headache ensues. This condition affects one's body organ like heart by several psychosomatic mech- 
anisms. So that heartbeat, blood circulations etc. are found to be increased due to excessive activation of sympathetic nerves. Symptoms of anger include teeth grinding, fist clenching, flushing, paling, prickly sensation, numbness, sweating, muscle tensions and temperature changes. Here the punishment center of the hypothalamus is stimulated from the external stimuli. As a result, there will be surge of catecholamines occur. The release of catecholamines triggers the fightor-flight response in the individual through activating the autonomic system. Stimulation of the lateral hypothalamus sometimes lead to overt rage and fighting.

Shoka (Grief): It is mental state precipitated by the loss of objects which are more beloved and in it Rajo Dosha is mainly involved. Vatadosha aggravates first then Pitta Dosha aggravation. The distress caused by Shoka can lead to many ill effects. Continuous exposure to Shoka for longer period can cause different physical diseases, emaciation and Agnivikriti. The victim suffering from grief is seen with weeping, feeling of self-insult, with dry mouth and throat, anemic and flaccid body having regular and long expirations. The degree of Shoka can be measured on the basis of intensity of Dainya. The victim of Shoka can suffer from diarrhoea, diabetes mellitus, insomnia and pyrexia etc. A man of "Hina Sattva" can pass into "Murchha" or even death due to the acuteness of Shokapersisting for a long time.

\section{Pathophysiological aspect of mansik vikara- ${ }^{3}$}

Shadkriyakalaja aspect-Manasikavikara as repressed negative thoughts and emotions vitiate Tridosha as a result these Doshas aggravate in their places called Sanchaya after this if causative factors are not prevented these Doshas start to affect brain and nervous system called Prakopa. This causes improper secretion and flowing of neuro-hormone (Prasara) to immune cells (Sthanasamsraya) affecting to body organs (Vyakta) and ultimately leading to physical diseases (Bheda). That is Psychic phase - Sanchaya, Psychoneurotic phase - Prakopa and Prasara, Psychosomatic phase - SthanaSamsraya and Vyakti and Advanced organic phase-Bhedavastha.

Mind (Emotions) and Body (Diseases) Relation-As Acharya Vagbhatta said that every disease occurs due to disturbance in digestive fire and Mansik Bhavas effects the digestive fire hence causing Sharirikvyadhi. Whenever Mansik bhavas like Krodh, Bhaya, Harsh, Chinta etc. (Anger and fear, excitement and anxiety) triggers the body's 'fight or flight and fright response'. The adrenal glands flood the body with stress hormones, such as adrenaline and cortisol. The brain shunts blood away from the gut and towards the muscles, in preparation for physical exertion. Heart rate, blood pressure and respiration increase, the body temperature rises, and the skin perspires. The mind is sharpened and focused. Constant flood of stress chemicals and associated metabolic changes can eventually cause harm to many different systems of the body causing short and long-term health problems. Mental tension, stress and strain, emotional instabilities like fear complexes (Phobias), etc. have tremendous somatic impact in bringing down the digestive power. In most of the diseases, Mansik Bhavas like Chinta, Bhaya, Shoka, Krodha are mentioned as causative factor (Nidana)which shows the relation explained in Ayurveda texts.For example-

- Shoka in Gulm nidana ${ }^{4}$

- Bhaya, Shoka, Harsh in Unmad Nidana

- Krodh, Shoka in Arsh Nidana

- Kaam, Chinta, Bhaya, Shoka in Pandurog and Kamala Nidana

- Krodh, Chinta in Kaasa Nidana

- Krodh, Irshya, Bhaya, Shoka in Atisaar Nidana ${ }^{9}$

- Shoka, Bhaya in Vaataj Chhardi Nidana ${ }^{10}$

- Kshobh, Bhaya, Shoka, Krodha in Trishna Nidana $^{11}$

- Chinta, Bhaya, Trasa in Hridyarog Nidana ${ }^{12}$

- Krodha, Chinta in Pratishyay Nidana ${ }^{13}$

- Shoka, bhaya, Krodha in Aruchi Nidana ${ }^{14}$

- Krodha in Vaatrakt Nidana ${ }^{15}$

- Atishoka in Shosha Nidana ${ }^{16}$

- Chinta, Shoka, Bhaya, Krodha in Ajirna ${ }^{17}$

- Krodha, Bhaya, Shoka in Madatyay ${ }^{18}$

- Shoka, Chinta, Bhaya in Beejopghatjanya Napunsakta $^{19}$

These are some examples and many more examples are there. Additionally, Ayurveda texts are mentioned 
the role of Mansik Bhavas in different physiological abnormalities which ultimately leads to different diseases. like-

- in Ojakshaya the treatment to reverse Kshaya is 'Pariharya visheshen mansahdukhahetvah' is given.

- In Dushti of Rasavahsrotas Atichinta is given as Hetu. $^{20}$

- In Vaatprakopak Kaaran, Krodh, Bhaya is included. ${ }^{21}$

Some Mansik Bhavas are indicated as Pathya - Apathya and even for Chikitsa like

- Harshani Kriya in Madatayay patients, ${ }^{22}$

- Krodh is Apathya in Visha, ${ }^{23}$

- in Vranchikitsa Rogi is indicated to be prevented from Glani. $^{24}$

This also implies that Mansik Vikaras not only causes diseases but can complicates the existing disease. Hence there is detailed description present on ancient Ayurveda texts which can specify the presence of relation between immunity and Mansik Bhavas.

Mansik Bhavas, Immunity and Vyadhi Utpatti ${ }^{25}$ Immunity is a condition of being able to resist a particular disease especially through preventing development of a pathogenic microorganism or by counteracting the effects of its products. It means that whenever any disease occurs there must be some loss of immunity in the related system and the factors responsible for the disease must be the cause for lowering the immune response. Is there any relation existing between Mansik Bhavas and immunity? How can Mansik Bhavas like anger (Krodha), grief (Shoka), anxiety (Chinta), fear (Bhaya) etc. can manipulate immune system? Behavioral and neuroendocrine mechanisms provide explanation about these questions. First, stress is associated with the activation of several neuroendocrine systems, including the hypothalamic - pituitary - adrenal (HPA) axis and the sympathetic nervous system (SNS). The activation of these two particular pathways results in elevated serum levels of Cortisol and catecholamines. Immune cells have receptors for these hormones, implying that they play a role in immune system modulation. Serum levels of Cortisol, epinephrine, and norepinephrine are also directly associated with various indicators of immunity. Recent evidence suggests, however, that the SNS is associated with alterations in human immune function before the HPA axis has had sufficient time to respond with an increase in Cortisol. Thus, in the case of certain immune responses (e.g., Lymphocyte proliferation) it may be that the SNS plays a greater role in stress induced immune alteration than the HPA axis. It is also possible that other endocrine systems activated by stress play roles in altering immune responses following stressor exposure. These systems include prolactin, growth hormone, and the opioids.

An alternative kind of pathway that could account for the relation between stress and immunity involves the association of stress with specific behaviors that modulate immune response. Distressed persons sleepless, exercise less, have poorer diets, smokes more, and use alcohol and other drugs more often than nondistressed people. These behaviors have all been shown to alter immune response. The association of stressor exposure with immunity might, therefore, be accounted for by the health practices of stressed subjects being different from those of control.

\section{DISCUSSION}

Ayurveda knows this thousand years ago and that is why Acharyas mentioned that "Sharir is related with Manas and Manas is related with Sharir". That's why Acharyas mentioned different Mansik Bhavas as a Hetu for Sharirik disease. Acharyas also mentioned how different Mansikbhavas leads to vitiation of Sharirik doshas like "Kaamshokbhayadvaayu, Krodhatpittam, Tryomala"26. Immunity of the body always plays role in defending the body from different diseases. Immunity is always the first line of defense and always try to protect the body. Occurring of any disease can be indicator of the failure of the immune response. Different emotional behaviors (Mansik Bhavas) hence leads to disturbance in the immunity of the body and causes the disease.

How could psychological emotions (Mansik Bhavas) "get inside the body" to affect the immune response? First, sympathetic fibers descend from the brain into both primary (bone marrow and thymus) and second- 
ary (spleen and lymph nodes) lymphoid tissues fibers can release a wide variety of substances that influence immune responses by binding to receptors on white blood cells. Though all lymphocytes have adrenergic receptors, differential density and sensitivity of adrenergic receptors on lymphocytes may affect responsiveness to stress among cell subsets. For example, natural killer cells have both high-density and highaffinity $\beta_{2}$-adrenergic receptors, $B$ cells have high density but lower affinity, and $\mathrm{T}$ cells have the lowest density. Second, the hypothalamic-pituitary-adrenal axis, the sympathetic-adrenal-medullary axis, and the hypothalamic-pituitary-ovarian axis secrete the adrenal hormones epinephrine, norepinephrine, and cortisol; the pituitary hormones prolactin and growth hormone; and the brain peptides melatonin, $\beta$ endorphin, and enkephalin. These substances bind to specific receptors on white blood cells and have diverse regulatory effects on their distribution and function. Third, people's efforts to manage the demands of stressful experience sometimes lead them to engage in behaviors - such as alcohol use or changes in sleeping patterns - that also could modify immune system processes. Thus, behavior represents a potentially important pathway linking Mansik Bhavas with the immune system.

"Rogasarveapi mandeagnau" implies that all the diseases have Mandaagni as a common factor. Mansik Bhavas also causes diseases by the same factor. Whenever Mansik Bhavas like Krodh, Bhaya, Harsh, Chinta etc. (Anger and fear, excitement and anxiety) triggers the body's 'fight or flight and fright response'. The brain shunts blood away from the gut and towards the muscles, in preparation for physical exertion and due to lesser supply to the gut, indigestion occurs which ultimately leads to disease.

\section{CONCLUSION}

There is existence of deep relation between Mansik Bhavas and immunity which clarifies the "Parasparanubandh" between Manas and Sharir. Modern science also made some excellent progressions determining this relation under the psychoneuroimmunology. Ayurveda texts have hundreds of examples of presence of this relation. That is why Aacharrasayan is explained in $1^{\text {st }}$ chapter of Chikitsasthan, that is why there is explanation about Dharniyavegas, and there is existence of Satvavajya and Daivvyapashrya chikitsa in Ayurveda texts because Acharyas always known to the fact that "mind effects body".

\section{REFERENCES}

1. https://www.merriamwebster.com/dictionary/immunity

2. Kumar Jitendra, Gond Pushpa and Byadgi P.S., Critical Evaluation of Manas Roga in Ayurveda, Indian Journal of Agriculture and Allied Sciences, Volume:1, No.:2, year: 2015.

3. Saini Neera: Role Of Manas Vikara In Development of Psychosomatic Disorders, IAMJ: Volume 3; Issue7; July- 2015

4. Chaturvedi G, Pandey K, editor, (1st Ed.). Charak Samhita of Agnivesha Vol-2, chikitsasthana; gulmachikitsa: Chapter 5, verse 5. Varanasi: Chaukhambha Vishvabharti Prakashana, Reprint 2017; 199.

5. Chaturvedi G, Pandey K, editor, (1st Ed.). Charak Samhita of Agnivesha Vol-2, chikitsasthana; unmadachikitsa: Chapter9, verse 4, 9. Varanasi: Chaukhambha Vishvabharti Prakashana, Reprint 2017; 305,307 .

6. Chaturvedi G, Pandey K, editor, (1st Ed.). Charak Samhita of Agnivesha Vol-2, chikitsasthana; arshchikitsa: Chapter14, verse12,15. Varanasi: Chaukhambha Vishvabharti Prakashana, Reprint 2017; 421.

7. Chaturvedi G, Pandey K, editor, (1st Ed.). Charak Samhita of Agnivesha Vol-2, chikitsasthana; pandurogchikitsa: Chapter19, verse 9. Varanasi: Chaukhambha Vishvabharti Prakashana, Reprint 2017; 488.

8. Chaturvedi G, Pandey K, editor, (1st Ed.). Charak Samhita of Agnivesha Vol-2, chikitsasthana; kasachikitsa: Chapter18, verse 14. Varanasi: Chaukhambha Vishvabharti Prakashana, Reprint 2017; 534.

9. Chaturvedi G, Pandey K, editor, (1st Ed.). Charak Samhita of Agnivesha Vol-2, chikitsasthana; atisaarchikitsa: Chapter19, verse 6,8,11. Varanasi: Chaukhambha Vishvabharti Prakashana, Reprint 2017; $559.560,562$.

10. Chaturvedi G, Pandey K, editor, (1st Ed.). Charak Samhita of Agnivesha Vol-2, chikitsasthana; chhardichikitsa: Chapter20, verse 7. Varanasi: Chaukhambha Vishvabharti Prakashana, Reprint 2017; 579.

11. Chaturvedi G, Pandey K, editor, (1st Ed.). Charak Samhita of Agnivesha Vol-2, chikitsasthana; trishnachikitsa: Chapter 22, verse 4. Varanasi: Chaukhambha Vishvabharti Prakashana, Reprint 2017; 613.

12. Chaturvedi G, Pandey K, editor, (1st Ed.). Charak Samhita of Agnivesha Vol-2, chikitsasthana; trimarmiyachikitsa: Chapter 26, verse 77. Varanasi: 
Chaukhambha Vishvabharti Prakashana, Reprint 2017; 739.

13. Chaturvedi G, Pandey K, editor, (1st Ed.). Charak Samhita of Agnivesha Vol-2, chikitsasthana; trimarmiyachikitsa: Chapter 26, verse 104,143. Varanasi: Chaukhambha Vishvabharti Prakashana, Reprint 2017; 736,746 .

14. Chaturvedi G, Pandey K, editor, (1st Ed.). Charak Samhita of Agnivesha Vol-2, chikitsasthana; trimarmiyachikitsa: Chapter26, verse 124. Varanasi: Chaukhambha Vishvabharti Prakashana, Reprint 2017; 742 .

15. Chaturvedi G, Pandey K, editor, (1st Ed.). Charak Samhita of Agnivesha Vol-2, chikitsasthana; vaatraktchikitsa: Chapter 29, verse 7. Varanasi: Chaukhambha Vishvabharti Prakashana, Reprint 2017; 820.

16. Shastri A D, editor, (1st Ed.). Vol-2, Sushruta Samhita of Sushruta, uttartantra; shoshpratishedh Adhyaya: Chapter 41, verse 21. Varanasi: Chaukhambha Sanskrit Sansthan, reprint 2017; 321.

17. Chaturvedi G, Pandey K, editor, (1st Ed.). Charak Samhita of Agnivesha Vol-1, vimanasthana; trividhakukshiyavimananadhyay: Chapter 2, verse 9. Varanasi: Chaukhambha Vishvabharti Prakashana, Reprint 2017; 688 .

18. Shastri AD, editor, (1st Ed.). Vol-2, Sushruta Samhita of Sushruta, uttartantra; panatyaypratishedh Adhyaya: Chapter 47, verse 15,16. Varanasi: Chaukhambha Sanskrit Sansthan, reprint 2017; 422.

19. Chaturvedi G, Pandey K, editor, (1st Ed.). Charak Samhita of Agnivesha Vol-2, chikitsasthana; yonivyapatchikitsa: Chapter 30, verse 137-138. Varanasi: Chaukhambha Vishvabharti Prakashana, Reprint 2017; 860 .

20. Chaturvedi G, Pandey K, editor, (1st Ed.). Charak Samhita of Agnivesha Vol-1, vimanasthana; srotovimananadhyay: Chapter5, verse 3. Varanasi: Chaukhambha Vishvabharti Prakashana, Reprint 2017; 713.

21. Chaturvedi G, Pandey K, editor, (1st Ed.). Charak Samhita of Agnivesha Vol-2, chikitsasthana; vaatvyadhichikitsa: Chapter 29, verse 17. Varanasi: Chaukhambh Vishvabharti Prakashana, Reprint 2017; 779.

22. Chaturvedi G, Pandey K, editor, (1st Ed.). Charak Samhita of Agnivesha Vol-2, chikitsasthana; madatyaychikitsa: Chapter 25, verse 191. Varanasi: Chaukhambha Vishvabharti Prakashana, Reprint 2017; 694.

23. Chaturvedi G, Pandey K, editor, (1st Ed.). Charak Samhita of Agnivesha Vol-2, chikitsasthana; vishachikitsa: Chapter 23, verse 228. Varanasi: Chaukhambha Vishvabharti Prakashana, Reprint 2017; 664.

24. Chaturvedi G, Pandey K, editor, (1st Ed.). Charak Samhita of Agnivesha Vol-2, chikitsasthana; dvivraniyachikitsa: Chapter 25, verse 70. Varanasi: Chaukhambha Vishvabharti Prakashana, Reprint 2017; 708.
25. Herbert, T.B., \& Cohen, S. (1993). Stress and immunity in humans: a meta-analytic review. Psychosomatic Medicine, 55, 364-379.

26. Chaturvedi G, Pandey K, editor, (1st Ed.). Charak Samhita of Agnivesha Vol-2, chikitsasthana; jwarachikitsa: Chapter 3, verse 115.Varanasi: Chaukhambha Vishvabharti Prakashana, Reprint 2017; 125.

\section{Source of Support: Nil Conflict of Interest: None Declared}

How to cite this URL: Hemant Kumar et al: Understanding The Relation Between Mansik Bhavas And Vyadhi Utpatti W.S.R. Immunity. International Ayurvedic Medical Journal \{online\} 2020 \{cited September, 2020\} Available from: http://www.iamj.in/posts/images/upload/4461_4466.pdf 